\title{
Phosphorus fertilizing potential of biomass ashes and their effect on bioavailability of micronutrients in wheat (Triticum aestivum. L)
}

\author{
Inderpal Singh ${ }^{* 1}$, H. S. Thind ${ }^{2}$, Sandeep Sharma², Yadvinder Singh ${ }^{2}$, Mohammad Amin \\ Bhat $^{1}$ \\ ${ }^{1}$ Department of Soil Science, CCS Haryana Agricultural University, Hisar - 125001 (Haryana), INDIA \\ ${ }^{2}$ Department of Soil Science, Punjab Agricultural University, Ludhiana -141001 (Punjab), INDIA \\ *Corresponding author. E-mail: inderpal.ipsingh@gmail.com \\ Received: August 14, 2016; Revised received: January 6, 2017; Accepted: April 13, 2017
}

\begin{abstract}
Ashes from agricultural biomass in agro-based industries have been found to have most of the plant nutrients except nitrogen and sulphur but are treated as waste material. The present study was conducted to evaluate the potential of biomass ashes as source of $P$ and their effect on bioavailability of micronutrients in wheat crop. We conducted the pot experiment at glass house of the Department of Soil Science, Punjab Agricultural University, Ludhiana, India. The experiment consisted of combinations of four $P$ sources [bagasse ash (BA), rice husk ash (RHA), rice straw ash (RSA), fertilizer $P$ (Fert-P)] supplying $P$ at three levels $\left(10,20\right.$ and $30 \mu \mathrm{g} \mathrm{g}^{-1}$ ) along with one zero-P control. This experiment was laid out in completely randomized design (CRD) having three replications. Application of $\mathrm{P}$ through RSA produced significantly higher grain yield $\left(14.3 \mathrm{~g} \mathrm{pot}^{-1}\right)$ than $\mathrm{BA}\left(12.8 \mathrm{~g} \mathrm{pot}^{-1}\right)$ and RHA $\left(12.9 \mathrm{~g} \mathrm{pot}^{-1}\right)$ but statistically at par with Fert-P $\left(13.5 \mathrm{~g} \mathrm{pot}^{-1}\right)$. Grain Zn content decreased maximum than other micronutrients with application of $P$ from all sources, hence maximum increased $P / Z n$ ratio. Phosphorus applied from all the biomass ashes significantly increased biomass and yield over control. With increase in $\mathrm{P}$ application, micronutrients content in grain was significantly decreased, hence decreased bioavailability of micronutrients in wheat grain.
\end{abstract}

Keywords: Bagasse ash, Micronutrients, Phosphorus fractions, Rice husk ash, Rice straw ash

\section{INTRODUCTION}

The search for alternative fertilizer sources has become increasingly important due to drastic rise of prices for commercial fertilizers. Moreover, yield of many crops such as rice and wheat are now showing signs of fatigue and no longer exhibiting increased production with increased chemical fertilizer use. The stagnation or decline in wheat production raises concerns about the sustainability of such chemical inputs driven production system and the food security of the region (Ladha et al., 2003). The possible reasons for such yield stagnation are non-judicious use of nutrients in relation to amount, timing and balance, and less use of organics (Ladha et al., 2005). In such cases, repeated application of organic manures is often recommended to maintain soil fertility. However, the use of organic manures is generally decreasing because of farm mechanization and a decrease in the size of livestock. Because commercial fertilizer prices continue to rise, organic manures including agricultural waste biomass ashes remain a valuable alternative to commercial fertilizers (Bolan et al., 2004).

Bagasse and rice husk are important agro-industrial by -product wastes which are generally used as fuel in sugar and rice mill industry, respectively. In India, about $7.63 \mathrm{mt}$ of bagasse ash (BA) and $6.37 \mathrm{mt}$ of rice husk ash (RHA) are produced every year (Beri and Gupta, 2003). Large quantities of rice straw are converted to ash during various processes involved in its utilization for bioenergy. The disposal of these ashes has become a serious problem for mill owners, municipal administration and environmental organizations. These ashes contain nearly all the nutrients except $\mathrm{N}$ and $\mathrm{S}$, which are lost to the atmosphere during burning due to their conversion into gaseous form. These materials are cheap, easily available and can be effectively used as amendment in agriculture for soil fertility improvement; otherwise they will pollute the environment and encroach upon vast areas of productive land in their present mode of disposal. The use of wood ash as a soil amendment has been well documented in the United States (Vance 1996; Mitchell and Black 1997; Patterson et al., 2004). The lack of research on use of agricultural waste biomass ashes has resulted in regulators being reluctant to classify rice husk ash and bagasse ash as soil amendments until benefits resulting from its application have been demonstrated. Ashes as amendment have been found to increase soil $\mathrm{pH}$, availability of nutrients and improved physical properties of soils (Giovannini et al., 1993; Demeyer et al., 2001; 
Saarsalmi et al., 2001). Earlier studies showed increases in maize yield with the application of cocoa husk ash and alfalfa ash (Onwuka et al., 2007) and of rice yield with the application of rice husk ash (Prakash et al., 2007; Nwite et al., 2011). Ayeni et al. (2008) observed the direct application of cocoa pod husk ash at $10 \mathrm{t} \mathrm{ha}^{-1}$ increased grain yield of maize by $31 \%$ on a sandy loam Alfisol. Mozaffari et al. (2002) have observed an increase in maize yield accompanied by significant increase in $\mathrm{P}$ and $\mathrm{K}$ uptake with the application of alfalfa ash. Talashilkar and Chavan (1996) reported an increase in rice grain yield as well as $\mathrm{P}$ uptake with the application of RHA. Thind et al. (2012) also reported that the application of RHA and BA to wheat at the rate of $10 \mathrm{tha}^{-1}$ along with recommended fertilizers resulted in 25 and $24 \%$ increase in mean grain yield of wheat and 10 and $11 \%$ in subsequent rice crop in rice-wheat system, respectively. It is established that wheat responds more to $\mathrm{P}$ than rice in rice-wheat system (Yadvinder-Singh et al., 2009). Nutrient composition and other properties of ashes are affected by different factors. Firstly, the kind of biomass combusted influences the quality and the nutrient values of ashes. For example, $\mathrm{P}$ concentrations range from $0.01 \%$ in bagasse ash (Jamil et al., 2004) to about $0.5 \% \mathrm{P}$ in cocoa husk ash (Onwuka et al., 2007) and $0.09 \%$ in alfalfa stem fly ash (Mozaffari et al., 2002).

Fertilization with $\mathrm{P}$ increases cereal crop yields which help to meet growing food demand. These yield increases, have led to declines in concentration of micronutrients such as $\mathrm{Fe}, \mathrm{Zn}, \mathrm{Mn}$ and $\mathrm{Cu}$ in cereal grain (Fan et al., 2008; Murphy et al., 2008), which are often critical sources of micronutrients for humans (Cakmak 2008). Phosphorus applications have been reported to negatively affect the shoot and even grain $\mathrm{Zn}$ concentration in cereal crops (Stukenholtz et al., 1966; Ryan et al., 2008). In addition, complex interactions of $\mathrm{P}$ with cations such as $\mathrm{Mn}, \mathrm{Fe}$ and especially $\mathrm{Zn}$ are known to occur. Although the bioavailability of micronutrients in foods is difficult to determine, it can be predicted by the molar ratio of $\mathrm{P}$ to micronutrients (P/Zn) (Bohn et al., 2008; Ryan et al., 2008). The molar ratio of grain $P$ to micronutrients, therefore, could be also used as a simple indicator of micronutrients bioavailability (Zhang et al., 2010; Kutman et al., 2011). Furthermore, crop biomass ashes (rape meal ash, cereal ash and wheat straw ash) have been reported as an efficient $\mathrm{P}$ source comparable to commercial fertilizers (Schiemenz and EichlerLobermann, 2010). Therefore, this study was undertaken to evaluate the potential of biomass ashes as a source of $\mathrm{P}$ for wheat and their effect on bioavailability of micronutrients.

\section{MATERIALS AND METHODS}

Site of study: The pot experiment was conducted us- ing wheat crop at glass house of the department of Soil Science, Punjab Agricultural University, Ludhiana, India. At the initiation of the experiment, soil studied had sandy loam texture, $\mathrm{pH}$ of 7.23(1:2 soil water suspension), electrical conductivity was $0.21 \mathrm{ds}^{-1}$. Contents of soil organic carbon $\left(4.20 \mathrm{~g} \mathrm{~kg}^{-1}\right)$ and available $\mathrm{K}\left(226 \mathrm{~kg} \mathrm{ha}^{-1}\right)$ were medium and Olsen-P (13.15 $\mathrm{kg} \mathrm{ha}^{-1}$ ) (Olsen et al., 1954) was medium.

Experimental details: The soil was ground, passed through $2 \mathrm{~mm}$ sieve and was treated with four level of $\mathrm{P}$ from different four sources of $\mathrm{P}$ including three different ashes and one fertilizer. The experiment consisted of treatment combinations of four different phosphorus sources [bagasse ash (BA), rice husk ash (RHA), rice straw ash (RSA), fertilizer P (Fert-P)] and three $\mathrm{P}$ levels $\left(10,20\right.$ and $\left.30 \mu \mathrm{g} \mathrm{g}^{-1}\right)$ designated as $\mathrm{P}_{10}$, $\mathrm{P}_{20}$ and $\mathrm{P}_{30}$, respectively along with one $\mathrm{P}_{0}$ control. The screen house experiment was laid out in a completely randomized design with three replications. The $\mathrm{P}$ content of different biomass ashes (BA- $0.137 \%$, RHA $-0.082 \%$, RSA $-0.103 \%$ ) was determined and the rate of application of different biomass ashes was as per the P levels. Single superphosphate was used in P fertilizer treatment.

Six $\mathrm{kg}$ soil was filled in polythene lined earthen pots. The required amounts of different ashes were applied in each pot and mixed thoroughly. The soil in the pots was subjected to alternate wetting and drying cycles for 10 days to attain equilibrium. The double of recommended dose of $\mathrm{N}$ and $\mathrm{K}_{2} \mathrm{O}\left(100: 24 \mathrm{~kg} \mathrm{ha}^{-1}\right)$ were applied to wheat. Eight seeds of wheat were sown in each pot. After germination, plants were thinned to maintain 4 plants per pot. The soil in the pots was irrigated as and when required with distilled water.

Soil and plant analysis: Plants were harvested at two stages, half at maximum tillering stage (49 days after sowing) and remaining half at maturity stage. At maximum tillering stage the shoot samples were harvested with the help of steel blade. For collection of roots the polythene bags were taken out from the pots. The soil was washed gently with tap water from each polythene bag. The roots were separated and put in the stainless steel sieve and washed with tap water, water jet, acidified water and finally with double distilled water. The harvested shoot samples were also washed with acidified water, distilled water and double distilled water. The washed shoot and root samples were air dried in paper bags and then in oven at $65 \pm 2$ ${ }^{0} \mathrm{C}$. Thereafter, the shoot and root biomass was weighted for dry matter yield. Shoot and root samples were ground and stored in polythene bags for chemical analysis. At maturity, plants were harvested and weighed for total biomass (grain+straw) from each pot. Samples were threshed manually by beating against hard surface. After threshing, grain and straw samples were collected and weighted from each pot. The grain 
samples were counted for each pot. Representative soil sample from each pot was taken with steel tube auger. These samples were air dried, ground, sieved and stored in polythene bags for further chemical analysis. Olsen-P and available $\mathrm{K}$ in soil samples were determined using $0.5 \mathrm{~N} \mathrm{NaHCO}_{3}$ extractable $\mathrm{P}$ method (Olsen et al., 1954) and ammonium acetate extractable $\mathrm{K}$ using flame photometer (Jackson, 1973), respectively. Grain and straw samples were analyzed for total $\mathrm{P}$ and $\mathrm{K}$ content using Vanado-Molybdo-Phosphoric yellow colour method in nitric acid (Jackson, 1973) and flame photometer, respectively. For micronutrients $0.5 \mathrm{gm}$ of grounded sample taken in test tube and added $10 \mathrm{ml}$ of di-acid (distilled $\mathrm{HNO}_{3}$ and $\mathrm{HClO}_{4}$ in the ratio of 3:1) and determined using atomic absorption spectrophotometer.

Statistical analysis: Analysis of variance (ANOVA) was carried out using CPCS1 and LSD at 0.05 level of probability was used to test the significance of differences among treatment means. MS EXCEL (Microsoft Corporation, Red-land, CA, USA) was used for graphical representation of the results.

\section{RESULTS AND DISCUSSION}

Plant biomass, grain yield and straw yield: The application of $\mathrm{P}_{10}$ from RSA and Fert-P caused significant $(p=0.05)$ increase in shoot biomass over the $\mathrm{P}_{0}$ which further increased significantly at $\mathrm{P}_{20}$ (Table 1). However, BA as source of $P$ caused significant increase only at $\mathrm{P}_{20}$ but RHA failed to cause significant increase at all the $\mathrm{P}$ levels applied. Irrespective of $\mathrm{P}$ levels, shoot biomass was significantly higher when $\mathrm{P}$ was applied through RSA and Fert-P than BA which was significantly higher than RHA. Application of P, irrespective of sources, caused significant increase in shoot biomass with increase from $\mathrm{P}_{10}$ to $\mathrm{P}_{20}$ and also with further increase to $\mathrm{P}_{30}$. In all the sources, significant increase was resulted in root biomass at $\mathrm{P}_{10}$ over the $\mathrm{P}_{0}$ except RHA which caused significant increase at $\mathrm{P}_{30}$. With application of BA and RSA root biomass was further increased significantly when $\mathrm{P}$ was from $\mathrm{P}_{10}$ to $\mathrm{P}_{30}$. Irrespective of $\mathrm{P}$ levels, RHA produced minimum root biomass which was significantly increased in BA and RSA which further increased significantly in Fert$\mathrm{P}$. Irrespective of $\mathrm{P}$ sources, there was significantly increased in root biomass with increase in $\mathrm{P}$ level from $\mathrm{P}_{10}$ to $\mathrm{P}_{20}$.

Application of $\mathrm{P}_{10}$ caused significant increase in grain and straw yield over $\mathrm{P}_{0}$ in all sources except RHA which caused significant increase at $\mathrm{P}_{20}$. The application of $\mathrm{P}_{10}$ from RSA produced significantly higher grain yield than $\mathrm{P}_{10}$ from RHA. The application of $\mathrm{P}$ through RSA, irrespective of $\mathrm{P}$ levels, produced significantly higher grain yield as compared with $\mathrm{P}$ applied through BA and RHA, but yield was statistically at par with Fert-P. The application of $\mathrm{P}_{20}$, irrespective of $\mathrm{P}$ sources, increased the grain yield significantly as compared to $\mathrm{P}_{10}$. At the highest rate of $\mathrm{P}$ applied $\left(\mathrm{P}_{30}\right)$, the increase in the grain yield was $43,37,29$ and $27 \%$ in RSA, Fert-P, RHA and BA, respectively, over $\mathrm{P}_{0}$. The straw yield produced with application of RHA as source of $\mathrm{P}$ was significantly lower than all other $\mathrm{P}$ sources which were at par among themselves.

Yield attributing characters: The application of $\mathrm{P}_{10}$ from RSA and Fert-P; while $\mathrm{P}_{20}$ applied from BA and RHA caused significant $(\mathrm{p}=0.05)$ increase in plant height over $\mathrm{P}_{0}$ (Table 1). The application of $\mathrm{P}_{10}$ through RSA caused significantly higher plant height than $\mathrm{P}_{10}$ using BA and RHA. The plant height with application of RSA and Fert-P as source of $\mathrm{P}$, irrespective of $\mathrm{P}$

Table 1. Plant biomass, grain, straw yield $\left(\mathrm{g} \mathrm{pot}^{-1}\right)$ and yield attributing characters of wheat as influenced by various levels of phosphorus applied through different sources.

\begin{tabular}{|c|c|c|c|c|c|c|c|c|c|}
\hline P sources & $\begin{array}{l}\text { P levels } \\
\left(\mu g g^{-1}\right)\end{array}$ & $\begin{array}{l}\text { Shoot } \\
\text { biomass }\end{array}$ & $\begin{array}{l}\text { Root } \\
\text { biomass }\end{array}$ & $\begin{array}{l}\text { Grain } \\
\text { yield }\end{array}$ & $\begin{array}{l}\text { Straw } \\
\text { yield }\end{array}$ & $\begin{array}{l}\text { Plant } \\
\text { height } \\
\text { (cm) }\end{array}$ & $\begin{array}{l}\text { Effective } \\
\text { tiller count } \\
\text { plant }^{-1}\end{array}$ & $\begin{array}{l}\text { No of } \\
\text { grains } \\
\text { pot }^{-1}\end{array}$ & $\begin{array}{l}1000 \\
\text { grain } \\
\text { weight }\end{array}$ \\
\hline \multirow[t]{5}{*}{ P sources } & $\mathrm{BA}$ & 4.69 & 1.93 & 12.8 & 20.4 & 84.8 & 4.91 & 412 & 31.0 \\
\hline & RHA & 3.69 & 1.51 & 12.9 & 17.9 & 85.3 & 4.89 & 413 & 31.1 \\
\hline & RSA & 5.39 & 1.96 & 14.3 & 22.1 & 91.2 & 5.08 & 460 & 31.1 \\
\hline & Fert-P & 5.27 & 2.26 & 13.5 & 21.1 & 90.1 & 5.10 & 440 & 30.6 \\
\hline & $\operatorname{LSD}(0.05)$ & 0.579 & 0.224 & 0.90 & 2.17 & 4.45 & NS & 21.6 & NS \\
\hline \multirow[t]{4}{*}{ Levels } & 10 & 4.06 & 1.69 & 12.5 & 19.4 & 77.4 & 4.60 & 405 & 30.9 \\
\hline & 20 & 4.82 & 1.93 & 13.7 & 21.1 & 87.2 & 5.13 & 432 & 31.6 \\
\hline & 30 & 5.40 & 2.12 & 13.9 & 20.7 & 99.0 & 5.27 & 457 & 30.3 \\
\hline & $\operatorname{LSD}(0.05)$ & 0.501 & 0.194 & 0.78 & NS & 3.85 & 0.267 & 18.7 & NS \\
\hline \multicolumn{10}{|c|}{ Control vs Treatments } \\
\hline & $\begin{array}{l}\text { Treat- } \\
\text { ments }\end{array}$ & 4.76 & 1.91 & 13.3 & 20.4 & 87.8 & 5.00 & 431 & 30.9 \\
\hline & Control & 2.85 & 1.15 & 10.4 & 13.7 & 70.3 & 4.14 & 343 & 30.3 \\
\hline & $\operatorname{LSD}(0.05)$ & 0.738 & 0.286 & 1.14 & 2.77 & 5.67 & 0.393 & 27.4 & NS \\
\hline
\end{tabular}


Table 2. Phosphorus content (\%) and uptake $\left(\mathrm{mg} \mathrm{pot}^{-1}\right)$ in wheat as influenced by various levels of phosphorus applied through different sources.

\begin{tabular}{|c|c|c|c|c|c|c|c|c|c|}
\hline \multirow[t]{2}{*}{ P sources } & \multirow{2}{*}{$\begin{array}{l}\text { P levels } \\
\left(\mu \mathrm{g} \mathrm{g}^{-1}\right)\end{array}$} & \multicolumn{4}{|c|}{$P$ content } & \multicolumn{4}{|c|}{ P uptake } \\
\hline & & shoot & Root & grain & straw & shoot & root & grain & straw \\
\hline \multirow[t]{5}{*}{ P sources } & $\overline{\mathrm{BA}}$ & 0.301 & 0.162 & 0.245 & 0.052 & 14.1 & 3.15 & 31.2 & 10.3 \\
\hline & RHA & 0.309 & 0.177 & 0.241 & 0.051 & 11.4 & 2.66 & 31.1 & 9.10 \\
\hline & RSA & 0.291 & 0.180 & 0.251 & 0.046 & 15.6 & 3.53 & 35.9 & 10.2 \\
\hline & Fert-P & 0.253 & 0.183 & 0.267 & 0.055 & 13.5 & 4.12 & 36.1 & 11.6 \\
\hline & $\operatorname{LSD}(0.05)$ & 0.0340 & NS & 0.0205 & NS & 2.12 & 0.467 & 3.33 & 1.40 \\
\hline \multirow[t]{4}{*}{ Levels } & 10 & 0.278 & 0.166 & 0.236 & 0.045 & 11.3 & 2.79 & 30.0 & 8.73 \\
\hline & 20 & 0.291 & 0.178 & 0.252 & 0.051 & 13.8 & 3.43 & 36.1 & 10.6 \\
\hline & 30 & 0.298 & 0.183 & 0.265 & 0.056 & 15.9 & 3.87 & 39.6 & 11.6 \\
\hline & $\operatorname{LSD}(0.05)$ & NS & NS & 0.0177 & 0.0065 & 1.83 & 0.404 & 2.30 & 1.21 \\
\hline \multicolumn{10}{|c|}{ Control vs Treatments } \\
\hline & Treatments & 0.289 & 0.175 & 0.251 & 0.051 & 13.7 & 3.36 & 33.6 & 9.97 \\
\hline & Control & 0.266 & 0.190 & 0.221 & 0.038 & 7.7 & 2.16 & 23.3 & 4.07 \\
\hline & $\operatorname{LSD}(0.05)$ & NS & NS & 0.0261 & 0.0097 & 2.70 & 0.595 & 4.25 & 1.200 \\
\hline
\end{tabular}

Table 3. Zinc and iron content $\left(\mathrm{mg} \mathrm{kg}^{-1}\right)$ in wheat as influenced by various levels of phosphorus applied through different sources.

\begin{tabular}{|c|c|c|c|c|c|c|c|c|c|}
\hline \multirow[t]{2}{*}{ P sources } & \multirow{2}{*}{$\begin{array}{l}\text { P levels } \\
\left(\mu \mathrm{g} \mathrm{g}^{-1}\right)\end{array}$} & \multicolumn{4}{|c|}{ Zn content } & \multicolumn{4}{|c|}{ Fe content } \\
\hline & & Shoot & root & grain & straw & shoot & root & grain & straw \\
\hline \multirow[t]{5}{*}{ P sources } & $\mathrm{BA}$ & 71.2 & 64.0 & 39.4 & 9.51 & 426 & 693 & 71.0 & 190 \\
\hline & RHA & 71.5 & 68.5 & 36.9 & 8.68 & 411 & 685 & 62.0 & 172 \\
\hline & RSA & 70.9 & 49.4 & 36.6 & 9.79 & 526 & 667 & 47.7 & 237 \\
\hline & Fert-P & 70.9 & 54.2 & 36.6 & 9.63 & 471 & 656 & 55.7 & 210 \\
\hline & $\operatorname{LSD}(0.05)$ & NS & 4.6 & 2.28 & NS & 37.0 & NS & 8.25 & 5.5 \\
\hline \multirow[t]{4}{*}{ Levels } & 10 & 74.3 & 61.7 & 40.2 & 10.37 & 427 & 614 & 61.3 & 187 \\
\hline & 20 & 71.2 & 59.3 & 36.8 & 8.96 & 464 & 660 & 58.1 & 206 \\
\hline & 30 & 67.9 & 56.1 & 35.1 & 8.89 & 484 & 751 & 57.8 & 213 \\
\hline & $\mathrm{LSD}(0.05)$ & 4.17 & 3.98 & 1.98 & 0.748 & 32.1 & 54.9 & NS & 4.8 \\
\hline \multicolumn{10}{|c|}{ Control vs Treatments } \\
\hline & Treatments & 71.1 & 59.0 & 37.4 & 9.40 & 459 & 675 & 59.1 & 202 \\
\hline & Control & 82.0 & 84.1 & 46.2 & 13.05 & 404 & 666 & 81.4 & 185 \\
\hline & $\mathrm{LSD}(0.05)$ & 6.14 & 5.86 & 2.91 & 1.101 & 47.2 & NS & 10.51 & 7.0 \\
\hline
\end{tabular}

levels, was significantly higher than BA and RHA. Irrespective of $\mathrm{P}$ sources, the $\mathrm{P}$ levels increased plant height significantly with increase in $\mathrm{P}$ level from $\mathrm{P}_{10}$ to $\mathrm{P}_{20}$ and further to $\mathrm{P}_{30}$. Application of Fert-P at $\mathrm{P}_{10}$ resulted significant increase in effective tiller count over $\mathrm{P}_{0}$ which was further increased significantly at $\mathrm{P}_{20}$ - however biomass ashes caused significant increase only at $\mathrm{P}_{20}$. Application of $\mathrm{P}$, irrespective of sources, increased effective tiller count significantly with increase in $\mathrm{P}$ level from $\mathrm{P}_{10}$ to $\mathrm{P}_{20}$. Application of $\mathrm{P}_{10}$ from all the sources caused significant increase in grain number over $\mathrm{P}_{0}$ which further increased significantly at $\mathrm{P}_{30}$. Among the all $\mathrm{P}$ sources RSA resulted maximum grain number which was at par with Fert-P and significantly higher than BA and RHA. Thousand grain weight was not significantly affected with different $P$ sources and levels.
$P$ content: Among the $\mathrm{P}$ sources, irrespective of $\mathrm{P}$ levels, the $\mathrm{P}$ content in shoot biomass was significantly $(p=0.05)$ lower with application of Fert-P than all other $\mathrm{P}$ sources which were statistically at par among themselves (Table 2). Application of different $\mathrm{P}$ sources at different levels failed to cause significant effect in root $\mathrm{P}$ content. Application of $\mathrm{P}_{30}$ caused significant increase in $\mathrm{P}$ content in grain over the $\mathrm{P}_{0}$ in all sources except Fert-P which caused significant increase at $\mathrm{P}_{20}$. The application of $\mathrm{P}_{20}$ through Fert-P caused significantly higher $\mathrm{P}$ content in grain than $\mathrm{P}_{20}$ using RHA. Application of Fert-P, irrespective of $\mathrm{P}$ levels, caused significantly higher grain $\mathrm{P}$ content than BA and RHA. The application of $\mathrm{P}_{20}$ caused significant increase in $\mathrm{P}$ content in straw over the $\mathrm{P}_{0}$ in all sources except RSA which caused significant increase at $\mathrm{P}_{30}$. Different $P$ levels, irrespective of $P$ sources, increased 
Table 4. Copper and manganese content $\left(\mathrm{mg} \mathrm{kg}^{-1}\right)$ in wheat as influenced by various levels of phosphorus applied through different sources.

\begin{tabular}{|c|c|c|c|c|c|c|c|c|c|}
\hline \multirow[t]{2}{*}{ P sources } & \multirow{2}{*}{$\begin{array}{l}\text { P levels } \\
\left(\mu g^{-1}\right)\end{array}$} & \multicolumn{4}{|c|}{$\mathrm{Cu}$ content } & \multicolumn{4}{|c|}{ Mn content } \\
\hline & & shoot & Root & grain & $\overline{\text { Straw }}$ & shoot & root & grain & straw \\
\hline \multirow[t]{5}{*}{$\bar{P}$ sources } & $\overline{\mathrm{BA}}$ & 8.68 & 19.7 & 7.90 & 2.76 & 17.5 & 140 & 20.0 & 9.91 \\
\hline & RHA & 8.06 & 19.5 & 8.16 & 2.59 & 15.9 & 137 & 18.0 & 8.53 \\
\hline & RSA & 7.47 & 18.9 & 7.82 & 2.37 & 17.9 & 139 & 16.4 & 9.94 \\
\hline & Fert-P & 8.48 & 19.5 & 8.44 & 2.66 & 16.5 & 138 & 17.0 & 9.55 \\
\hline & $\operatorname{LSD}(0.05)$ & NS & NS & 0.468 & NS & 1.46 & NS & 1.20 & 0.438 \\
\hline \multirow[t]{4}{*}{ Levels } & 10 & 8.95 & 21.4 & 8.58 & 2.84 & 17.4 & 130 & 18.1 & 10.3 \\
\hline & 20 & 7.80 & 18.9 & 7.87 & 2.40 & 17.0 & 141 & 17.7 & 9.46 \\
\hline & 30 & 7.77 & 18.0 & 7.79 & 2.55 & 16.4 & 146 & 17.7 & 8.69 \\
\hline & $\operatorname{LSD}(0.05)$ & 0.986 & 0.97 & 0.406 & 0.275 & NS & 6.8 & NS & 0.379 \\
\hline \multicolumn{10}{|c|}{ Control vs Treatments } \\
\hline & Treatments & 8.17 & 19.4 & 8.08 & 2.59 & 16.9 & 139 & 17.9 & 9.48 \\
\hline & Control & 9.98 & 25.5 & 9.18 & 3.17 & 14.6 & 114 & 24.3 & 8.18 \\
\hline & $\operatorname{LSD}(0.05)$ & 1.452 & 1.43 & 0.597 & 0.405 & 1.86 & 10.1 & 1.53 & 0.558 \\
\hline
\end{tabular}

Table 5. $\mathrm{P} / \mathrm{Zn}$ and $\mathrm{P} / \mathrm{Fe}$ ratio in wheat as influenced by various levels of phosphorus applied through different sources.

\begin{tabular}{|c|c|c|c|c|c|c|c|c|c|}
\hline \multirow[t]{2}{*}{ P sources } & \multirow{2}{*}{$\begin{array}{l}\text { P levels } \\
\left(\mu g g^{-1}\right)\end{array}$} & \multicolumn{4}{|c|}{$\mathbf{P} / \mathbf{Z n}$} & \multicolumn{4}{|c|}{$\mathrm{P} / \mathrm{Fe}$} \\
\hline & & shoot & root & grain & straw & shoot & root & grain & straw \\
\hline \multirow[t]{5}{*}{ P sources } & $\mathrm{BA}$ & 42.5 & 25.6 & 59.1 & 48.5 & 7.08 & 2.39 & 27.0 & 2.87 \\
\hline & RHA & 43.6 & 26.2 & 58.2 & 48.0 & 7.64 & 2.63 & 26.6 & 2.84 \\
\hline & RSA & 41.1 & 37.3 & 60.6 & 43.2 & 5.55 & 2.75 & 27.7 & 2.55 \\
\hline & Fert-P & 35.7 & 34.1 & 64.4 & 51.7 & 5.47 & 2.82 & 29.4 & 3.05 \\
\hline & $\operatorname{LSD}(0.05)$ & 4.81 & 4.73 & NS & NS & 0.971 & NS & NS & NS \\
\hline \multirow[t]{4}{*}{ Levels } & 10 & 37.4 & 27.7 & 57.0 & 42.5 & 6.65 & 2.78 & 26.0 & 2.51 \\
\hline & 20 & 40.9 & 30.7 & 60.8 & 48.2 & 6.44 & 2.73 & 27.8 & 2.85 \\
\hline & 30 & 43.8 & 34.0 & 63.9 & 53.0 & 6.22 & 2.44 & 29.2 & 3.13 \\
\hline & $\operatorname{LSD}(0.05)$ & 4.17 & 4.10 & 4.28 & 6.18 & NS & NS & 1.96 & 0.365 \\
\hline \multicolumn{10}{|c|}{ Control vs Treatments } \\
\hline & Treatments & 40.7 & 30.8 & 60.6 & 47.9 & 6.43 & 2.65 & 27.7 & 2.83 \\
\hline & Control & 32.9 & 22.6 & 53.3 & 35.5 & 6.6 & 2.86 & 24.4 & 2.10 \\
\hline & $\operatorname{LSD}(0.05)$ & 6.14 & 6.04 & 6.31 & 9.10 & NS & NS & 2.88 & 0.538 \\
\hline
\end{tabular}

$\mathrm{P}$ content in straw significantly with increase in $\mathrm{P}$ level from $\mathrm{P}_{10}$ to $\mathrm{P}_{30}$.

$P$ uptake: Application of $\mathrm{P}_{20}$ from all sources caused significant $(p=0.05)$ increase in $P$ uptake in shoot over the $\mathrm{P}_{0}$ except RSA which caused significant increase at $\mathrm{P}_{10}$ (Table 2). The application of $\mathrm{P}_{20}$ using RSA caused significantly higher $\mathrm{P}$ uptake in shoot than $\mathrm{P}_{20}$ from RHA. Irrespective of P levels, the P uptake in shoot with application of RHA as source of $\mathrm{P}$ was significantly lower than BA and RSA and statistically at par in Fert-P. There was significant increase in shoot $\mathrm{P}$ uptake with increase in $\mathrm{P}$ level from $\mathrm{P}_{10}$ to $\mathrm{P}_{20}$ which further increased to $\mathrm{P}_{30}$. Application of $\mathrm{P}_{10}$ from Fert- $\mathrm{P}$ while $\mathrm{P}_{20}$ applied through $\mathrm{BA}$ and RSA caused significant increase in $\mathrm{P}$ uptake in root over the $\mathrm{P}_{0}$ but RHA caused significant increase at $\mathrm{P}_{30}$. Application of $\mathrm{P}_{30}$ from Fert-P caused significantly higher $\mathrm{P}$ uptake in root than $\mathrm{P}_{30}$ from BA and RHA. The lowest $\mathrm{P}$ uptake in root was recorded in RHA, irrespective of $\mathrm{P}$ levels, which increased significantly in BA and RSA which further significantly increased in Fert-P.

Grain $\mathrm{P}$ uptake was significantly increased with $\mathrm{P}_{10}$ applied from RSA and Fert-P over the $\mathrm{P}_{0}$ but BA and RHA caused significant increase only at $\mathrm{P}_{20}$. Application of Fert-P, irrespective of $\mathrm{P}$ levels, caused significantly higher $\mathrm{P}$ uptake in grain than BA and RHA. Application of $\mathrm{P}_{10}$ resulted significant increase in straw $\mathrm{P}$ uptake over $\mathrm{P}_{0}$ in all sources except RHA which caused significant increase at $\mathrm{P}_{20}$. With increase in $\mathrm{P}$ level from $\mathrm{P}_{10}$ to $\mathrm{P}_{20}$ with application of RSA and 
Inderpal Singh et al. / J. Appl. \& Nat. Sci. 9 (2): 744 - 753 (2017)

Table 6. $\mathrm{P} / \mathrm{Cu}$ and $\mathrm{P} / \mathrm{Mn}$ ratio in wheat as influenced by various levels of phosphorus applied through different sources.

\begin{tabular}{|c|c|c|c|c|c|c|c|c|c|}
\hline \multirow[t]{2}{*}{ P sources } & \multirow{2}{*}{$\begin{array}{l}\text { P levels } \\
\left(\mu g g^{-1}\right)\end{array}$} & \multicolumn{4}{|c|}{$\mathbf{P} / \mathrm{Cu}$} & \multicolumn{4}{|c|}{ P/Mn } \\
\hline & & shoot & root & grain & straw & $\begin{array}{l}\text { shoot } \\
\text { s. }\end{array}$ & root & grain & Straw \\
\hline \multirow[t]{5}{*}{ P sources } & $\mathrm{BA}$ & 358 & 82.4 & 310 & 147 & 174 & 11.6 & 129 & 44.8 \\
\hline & RHA & 393 & 92.5 & 305 & 146 & 197 & 12.8 & 127 & 44.3 \\
\hline & RSA & 396 & 96.7 & 318 & 131 & 164 & 13.0 & 132 & 39.9 \\
\hline & Fert-P & 304 & 94.7 & 338 & 157 & 155 & 13.3 & 140 & 47.7 \\
\hline & $\operatorname{LSD}(0.05)$ & 64.3 & NS & NS & NS & 25.7 & NS & NS & NS \\
\hline \multirow[t]{4}{*}{ Levels } & 10 & 320 & 78.2 & 299 & 129 & 160 & 12.8 & 124 & 39.2 \\
\hline & 20 & 379 & 93.9 & 319 & 146 & 173 & 12.7 & 133 & 44.5 \\
\hline & 30 & 389 & 103 & 335 & 161 & 184 & 12.5 & 139 & 48.9 \\
\hline & $\operatorname{LSD}(0.05)$ & 55.7 & 10.3 & 22.5 & 18.8 & NS & NS & 9.3 & 5.71 \\
\hline \multicolumn{10}{|c|}{ Control vs Treatments } \\
\hline & Treatments & 363 & 91.6 & 318 & 145 & 172 & 12.7 & 132 & 44.2 \\
\hline & Control & 270 & 74.6 & 280 & 108 & 183 & 16.9 & 116 & 32.8 \\
\hline & $\operatorname{LSD}(0.05)$ & 82.0 & 15.2 & 33.1 & 27.6 & NS & 2.36 & 13.8 & 8.40 \\
\hline
\end{tabular}

Table 7. Soil $\mathrm{pH}, \mathrm{EC}\left(\mathrm{dSm}^{-1}\right)$, Olsen-P $\left(\mathrm{kg} \mathrm{ha}^{-1}\right)$ and $\mathrm{P}$ fractions $\left(\mu \mathrm{g} \mathrm{g}^{-1}\right)$ as influenced by various levels of phosphorus applied through different sources.

\begin{tabular}{|c|c|c|c|c|c|c|c|c|}
\hline \multirow[t]{2}{*}{ P sources } & \multirow[t]{2}{*}{ P levels $\left(\mu \mathrm{g} \mathrm{g}^{-1}\right)$} & \multicolumn{3}{|c|}{ Parameters } & \multicolumn{4}{|c|}{ P fractions } \\
\hline & & pH & EC & Olsen-P & Al-P & Fe-P & Ca-P & Org-P \\
\hline \multirow[t]{5}{*}{ P sources } & $\mathrm{BA}$ & 7.47 & 0.229 & 7.53 & 14.4 & 43.5 & 547 & 77.8 \\
\hline & RHA & 7.53 & 0.228 & 7.55 & 14.0 & 42.4 & 556 & 77.7 \\
\hline & RSA & 7.65 & 0.231 & 7.74 & 14.3 & 47.2 & 570 & 80.1 \\
\hline & Fert-P & 7.19 & 0.230 & 7.60 & 14.3 & 44.0 & 577 & 79.4 \\
\hline & $\operatorname{LSD}(0.05)$ & 0.06 & NS & NS & NS & NS & NS & NS \\
\hline \multirow[t]{4}{*}{ Levels } & 10 & 7.39 & 0.228 & 7.12 & 13.4 & 41.6 & 482 & 74.6 \\
\hline & 20 & 7.47 & 0.230 & 7.57 & 14.4 & 44.9 & 571 & 79.1 \\
\hline & 30 & 7.52 & 0.230 & 8.12 & 14.9 & 46.4 & 635 & 82.5 \\
\hline & $\operatorname{LSD}(0.05)$ & 0.052 & NS & 0.197 & 1.11 & NS & 40.1 & 4.63 \\
\hline \multicolumn{9}{|c|}{ Control vs Treatments } \\
\hline & Treatments & 7.46 & 0.230 & 7.60 & 14.3 & 44.3 & 562 & 78.7 \\
\hline & Control & 7.23 & 0.228 & 6.74 & 12.2 & 37.1 & 388 & 67.7 \\
\hline & $\operatorname{LSD}(0.05)$ & 0.076 & NS & 0.289 & 1.64 & 6.96 & 59.1 & 6.82 \\
\hline
\end{tabular}

from $\mathrm{P}_{10}$ to $\mathrm{P}_{30}$ with application of Fert-P resulted significant increase in straw $\mathrm{P}$ uptake. Application of $\mathrm{P}_{10}$ through BA caused significantly higher $\mathrm{P}$ uptake in straw than $\mathrm{P}_{10}$ using RHA. The application of $\mathrm{P}_{30}$ from Fert-P caused significant higher $P$ uptake in straw than with $\mathrm{P}_{30}$ from $\mathrm{BA}$ and RHA. The $\mathrm{P}$ uptake in straw with application of RHA caused significantly lower than all other $\mathrm{P}$ sources which were at par among themselves.

Micronutrients content: Zinc content was significantly $(p=0.05)$ decreased with increase in P levels, irrespective of $\mathrm{P}$ sources in shoot, root, grain and straw (Table 3 ). Grain $\mathrm{Zn}$ content was significantly decreased with increase in $\mathrm{P}$ level from $\mathrm{P}_{10}$ to $\mathrm{P}_{20}$ with application of RHA and RSA and from $\mathrm{P}_{10}$ to $\mathrm{P}_{30}$ using Fert-P. The application of $\mathrm{P}_{30}$ caused decrease in the grain $\mathrm{Zn}$ content which was 28, 25, 25 and $18 \%$ in Fert-P, RHA, RSA and BA, respectively, over $\mathrm{P}_{0}$. The results revealed that shoot, root and straw $\mathrm{Fe}$ and $\mathrm{Mn}$ content were significantly increased with increasing $\mathrm{P}$ levels (Table 3, 4). But grain Fe content was significantly decreased with increase in $\mathrm{P}$ application. Application of $\mathrm{P}_{10}$ from RSA and Fert- $\mathrm{P}$ while $\mathrm{P}_{20}$ applied from BA and RHA caused significant decrease in grain $\mathrm{Fe}$ content over the $\mathrm{P}_{0}$. Within application of different biomass ashes, the lowest $\mathrm{Fe}$ content in grain was recorded in RSA which significantly increased in RHA which further increased significantly in BA. Application of $\mathrm{P}_{10}$ caused significant decrease in $\mathrm{Mn}$ content in grain in all the sources over the $\mathrm{P}_{0}$ which was further significantly increased with increase in $\mathrm{P}$ level from $\mathrm{P}_{20}$ to $\mathrm{P}_{30}$ with application of Fert-P. Root, grain and straw $\mathrm{Cu}$ content showed significant decrease with increasing $\mathrm{P}$ levels, however, maximum decrease was with application of RSA (Table 4). Application of $\mathrm{P}_{10}$ from BA while $\mathrm{P}_{20}$ applied from RHA and RSA caused 
significant decrease in grain $\mathrm{Cu}$ content over the $\mathrm{P}_{0}$ but Fert-P caused significant decrease at $\mathrm{P}_{30}$. There was significant increase in $\mathrm{Cu}$ content in grain with increase in $\mathrm{P}$ level from $\mathrm{P}_{20}$ to $\mathrm{P}_{30}$ through RSA. Application of Fert-P, irrespective of $\mathrm{P}$ levels, caused significant higher $\mathrm{Cu}$ content in grain than BA and RSA.

Molar ratio of $\mathbf{P}$ to micronutrients: Molar ratio is the concentration ratio with one nutrient to other nutrient which gives the idea how one nutrient concentration effects other. Molar ratio of $\mathrm{P} / \mathrm{Zn}$ in shoot, root, grain and straw was significantly $(\mathrm{p}=0.05)$ increased by as much as 1.5 to 2 fold with increasing $\mathrm{P}$ levels which showed with increase in $\mathrm{P}$ concentration in biomass decreased the $\mathrm{Zn}$ concentration due to antagonistic effect (Table 5). $\mathrm{P} / \mathrm{Cu}$ in biomass, grain and straw was also significantly increased with $\mathrm{P}$ applied from different sources (Table 6). Application of $\mathrm{P}_{20}$ from Fert-P while $\mathrm{P}_{30}$ from $\mathrm{BA}$ and RSA caused significant increase in grain $\mathrm{P} / \mathrm{Cu}$ over the $\mathrm{P}_{0}$ while $\mathrm{RHA}$ was failed to cause significant affect. The $\mathrm{P} / \mathrm{Fe}$ and $\mathrm{P} / \mathrm{Mn}$ in shoot and root resulted no significant effect with $\mathrm{P}$ application, however, grain and straw molar ratio significantly increased with P applied.

Soil $\mathbf{p H}$, electrical conductivity and Olsen-P: The application of $\mathrm{P}$ at different rates from different sources significantly $(\mathrm{p}=0.05)$ affected the soil $\mathrm{pH}$ (Table 7). Application of $\mathrm{P}_{10}$ caused significant increase in soil $\mathrm{pH}$ over the $\mathrm{P}_{0}$ in all sources except Fert-P which failed to cause significant affect in soil $\mathrm{pH}$. There was further significant increase in soil $\mathrm{pH}$ with increase in $\mathrm{P}$ level from $\mathrm{P}_{10}$ to $\mathrm{P}_{20}$ with application of BA, RHA and RSA. The application of $\mathrm{P}_{10}$ and $\mathrm{P}_{20}$ through RSA caused significantly higher soil $\mathrm{pH}$ than $\mathrm{P}_{10}$ and $\mathrm{P}_{20}$ using all other sources. Irrespective of $\mathrm{P}$ levels, application of RSA caused significant increase in soil $\mathrm{pH}$ than $\mathrm{P}$ from BA and RHA which were statistically at par among themselves. Application of $\mathrm{P}$ from different sources failed to cause significant effect on soil EC. Phosphorus applied from different sources significantly increased Olsen- extractable P (Table 7). Olsen-P was significantly increased with increase in $\mathrm{P}$ level from $\mathrm{P}_{20}$ to $\mathrm{P}_{30}$ with application of $\mathrm{BA}$ and from $\mathrm{P}_{10}$ to $\mathrm{P}_{30}$ with application of RHA, RSA and Fert-P.

$P$ fractions: Phosphorus applied through different biomass ashes failed to cause significant effect in all the $\mathrm{P}$ fractions. But with increase in $\mathrm{P}$ levels, significant $(p=0.05)$ increase was showed in Al-P, Ca-P and Org$\mathrm{P}$ content. The application of $\mathrm{P}_{10}$ caused significant increase in Ca-P content over the $\mathrm{P}_{0}$ using all sources except BA which caused significant increase at $\mathrm{P}_{20}$. There was further significant increase in $\mathrm{Ca}-\mathrm{P}$ content with increase in $\mathrm{P}$ level from $\mathrm{P}_{10}$ to $\mathrm{P}_{30}$ with application of Fert-P and from $\mathrm{P}_{10}$ to $\mathrm{P}_{20}$ using RHA and RSA.

The results of the present study showed that wheat grain and straw yield increased with addition of biomass ashes, which is in accordance with the results of Thind et al. (2012) who reported that the application of RHA and $\mathrm{BA}$ to wheat at the rate $10 \mathrm{t} \mathrm{ha}^{-1}$ along with recommended fertilizer resulted in 25 and $24 \%$ increase in mean grain yield of wheat. The significant $(p=0.05)$ increase in grain yield with the application of RHA and BA seems to be attributed to the increased availability of nutrients and favorable effects of ashes on soil physical conditions and microbial processes (Demeyer et al., 2001). Nwite et al. (2011) reported that RHA produced significantly higher maize yield $\left(5.75 \mathrm{t} \mathrm{ha}^{-1}\right)$ than wood ash $\left(1.51 \mathrm{t} \mathrm{ha}^{-1}\right)$ and leaf ash $\left(0.60 \mathrm{t} \mathrm{ha}^{-1}\right)$ when these ashes were applied at the rate of $3 \mathrm{t} \mathrm{ha}^{-1}$. Lopez et al. (2009) reported that sugarcane ash produced significantly higher lettuce yield and $\mathrm{P}$ uptake over control. They also observed that application of rape meal ash produced significantly higher yield of ryegrass and oil radish as compared with control. Significant increases in yield of ryegrass and oil radish were accompanied by significant increase in plant $\mathrm{P}$ uptake. In our experiment application of RSA statistically showed similar yield to Fert-P which may be ascribed to fact that RSA has the ability to buffer the soil which may initiate the release of available nutrients in the soil, which is in agreement with the findings of Bachmann and Eichler-lobermann (2010), who reported that application poultry litter ash produced statistically similar yield of ryegrass and oil radish and plant $\mathrm{P}$ uptake to fertilizer $\mathrm{P}\left(\mathrm{KH}_{2} \mathrm{PO}_{4}\right)$ applied.

Jamil et al. (2004) investigated the effects of BA on the yield of wheat and reported that application of BA at the rate $2.0 \%$ caused significant increase in plant height, spike length, number of productive tillers $\mathrm{m}^{-2}$, number of grains spike ${ }^{-1}$ and grain yield over control. Priyadharshini and Seran (2009) reported that application $4.5 \mathrm{t}$ RHA ha ${ }^{-1}$ produced higher number of nodules, pods per plants and 100 seed weight of cowpea over control. Adjei-Nsiah and Obeng (2013) reported that application of palm bunch ash (PBA) produced significantly higher fruits per plant, fruit length and fresh fruit yield of okra per plant over control. Akanbi et al. (2014) observed that the application of $6 \mathrm{t}$ PBA $\mathrm{ha}^{-1}$ caused significant increase in plant height, leaf area, number of leaves, girth of cocoa seedlings over control. Majeed et al. (2014) reported that increase in the application rate of fertilizer $P$ from 0 to $60 \mathrm{~kg}$ $\mathrm{ha}^{-1}$ significantly increased the wheat plant height and effective tiller count. Increase in plant height as compared to control treatment might have been due to that $\mathrm{P}$ stimulates root development and growth in the seedling stage and thereby it helps to establish the seedling quickly and Increase in number of fertile tillers with $\mathrm{P}$ might have been due to balanced fertilizer application, which might have resulted in better plant growth and more number of total tillers per unit area. The findings are in accordance with the investigations of Pareek et al. (2004) and Memon et al. (2005) who reported that $\mathrm{P}$ application increases plant height and number of fertile tillers in wheat. 
Total uptake was significantly increased with increase in P levels. Fageria (2014) reported that P uptake in shoot as well as in grain was significantly increased with increase in $\mathrm{P}$ levels from 0 to $200 \mathrm{mg} \mathrm{kg}$. Hence the overall total $\mathrm{P}$ uptake was also increased. Mehla et al. (2006) reported that grain yield and P uptake of rice increased significantly with the combined use of RHA and fertilizer N compared with fertilizer $\mathrm{N}$ alone.

Sammauria and Yadav (2010) reported that with application of $\mathrm{P}$ at the rate of $26.2 \mathrm{~kg} \mathrm{P} \mathrm{ha}^{-1}$, significant decrease in $\mathrm{Zn}$ content of seed and straw of fenugreek was observed as compared with control. They observed that the decrease in $\mathrm{Zn}$ content might be due to the reduced translocation of $\mathrm{Zn}$ in plant body under environment of increased concentration of P. Imtiaz et al. (2006) reported that at $\mathrm{Zn}$-deficient level, $\mathrm{Zn}$ concentrations in the wheat shoot decreased with increase in level of $\mathrm{P}$ and more severe $\mathrm{Zn}$ deficiency was observed at the $P$ level of $250 \mathrm{mg} \mathrm{g}^{-1}$ soil. They also reported that $\mathrm{P}$-induced $\mathrm{Zn}$ deficiency is accompanied by decrease in chlorophyll and $\mathrm{Cu} / \mathrm{Zn}$ superoxide dismutase activity.

With regard to molar ratio of $\mathrm{P}$ to micronutrients, Zhang et al. (2012) observed that the molar ratios of $\mathrm{P} /$ $\mathrm{Zn}$ and $\mathrm{P} / \mathrm{Cu}$ in grain and straw of wheat was significantly increased with $\mathrm{P}$ application. The increased $\mathrm{P} / \mathrm{Zn}$ would suggest potentially decreased $\mathrm{Zn}$ bioavailability due to $\mathrm{P}$ applications. Izsaki (2014) observed that with increase in application of $\mathrm{P}$ from 120 to $339 \mathrm{mg} \mathrm{kg}^{-1}$ there was significant decrease in $\mathrm{Zn}$ and $\mathrm{Cu}$ concentrations in maize leaves. They further reported that $\mathrm{P} / \mathrm{Zn}$ and $\mathrm{P} / \mathrm{Cu}$ was significantly increased with increase in $\mathrm{P}$ application.

The application of different biomass ash increased the soil $\mathrm{pH}$. Similar results were reported by Okon et al. (2005) that application of RHA significantly increased soil $\mathrm{pH}$ from 4.9 to 6.0 in acid sands under okra cultivation. Njoku and Mbah (2012) observed significantly increased the soil $\mathrm{pH}$ when amendment with RHA over the control in maize under ultisols. Lopez et al. (2009) reported that poultry litter ash caused significantly increase the soil $\mathrm{pH}$ over control.under field conditions. Akanbi et al. (2014) observed that application of PBA significantly increases soil $\mathrm{pH}$ from 6.4 to 7.85 compared to control. The increase in the $\mathrm{pH}$ of the soil after the application of the PBA was due to the high $\mathrm{pH}$ level of the PBA and relatively high levels of $\mathrm{Ca}$ and $\mathrm{Mg}$ which had liming effect on the soil. Nwite et al. (2011) reported that application of RHA at the rate of $3 \mathrm{t} \mathrm{ha}^{-1}$ caused significant increase in available $\mathrm{P}\left(8.22\right.$ to $\left.31.4 \mathrm{mg} \mathrm{ha}^{-1}\right)$, cation exchange capacity ( 3.24 to $5.34 \mathrm{cmol}(+) \mathrm{kg}^{-1}$ ). Ayeni et al. (2008) reported that cocoa pod ash at the rate of $10 \mathrm{t} \mathrm{ha}^{-1}$ significantly increased soil organic matter and soil $\mathrm{P}$ by 71 and $45 \%$, respectively. Gupta et al. (2013) reported that application of RHA and BA at the rate of $10 \mathrm{t} \mathrm{ha}^{-1}$ to both wheat and rice caused significant increase in Al-P, Fe-P, Ca-P and Olsen-P over control. Sihag et al. (2005) reported that organic ashes significantly increased the amount of $\mathrm{P}$ recovered in $\mathrm{Fe}-\mathrm{P}, \mathrm{Al}-\mathrm{P}$ and $\mathrm{Ca}-\mathrm{P}$ over control in rice-wheat cropping system. Bachmann and Eichler-lobermann (2010) reported that the application of poultry litter ash caused significant increase of most bioavailable resin $\mathrm{P}$ fraction and failed to cause significant increase in $\mathrm{Na}$ $\mathrm{HCO}_{3}-\mathrm{P}$ and $\mathrm{NaOH}-\mathrm{P}$ in catch crop cultivation.

\section{Conclusion}

Phosphorus applied through all the biomass ashes resulted in significant increase in root, shoot biomass, grain and straw yield over control. Among biomass ashes $\mathrm{P}$ applied from RSA (14.3 $\mathrm{g} \mathrm{pot}^{-1}$ ) produced significantly higher yield which was statistically at par with P from Fert-P (13.5 g pot $^{-1}$ ). Phosphorus uptake was significantly increased with $\mathrm{P}$ applied through biomass ashes which were comparable to Fert-P. Application of $\mathrm{P}$ from all sources resulted in significant decrease in micronutrients content in grain, which increased molar ratio of $\mathrm{P}$ to micronutrient showed decreased bioavailability of micronutrients in grain. Phosphorus applied from all the biomass ashes recorded significant increase in soil $\mathrm{pH}$ while $\mathrm{P}$ from Fert-P did not show any effect on soil $\mathrm{pH}$. Application of $\mathrm{P}$ through biomass ashes resulted in significant increase in Olsen-P over control which further increased with increase in $\mathrm{P}$ levels which showed similar affect like Fert-P. Therefore, application of biomass ashes can act as substitute for fertilizer $\mathrm{P}$ as well as the disposal problem can be averted without creating environmental hazard.

\section{REFERENCES}

Adjei-Nsiah, S. and Obeng, C. B. (2013). Effect of palm bunch ash application on soil and plant nutrient composition, growth and yield of garden eggs, pepper and okra. Inter. J. Pl. Soil. Sci., 2: 1-15

Akanbi, O. S., Ojeniyi, S. O. and Famaye, A. O. (2014). Soil nutrients and cocoa seedling performance as influenced by plant residue ash and NPK fertilizer addition on a depleted soil in Ibadan, south western, Nigeria. Int. Res. J. Agric. Sci. Soil. Sci., 4: 1-4

Ayeni, L. S., Adetunji, M. T., Ojeniyi, S. O., Ewulo, B. S. and Adeyemo, A. J. (2008). Comparative and cumulative effect of cocoa pod husk ash and poultry manure on soil and maize nutrient contents and yield. Am-Eu. J. Sustain. Agric., 2: 92-97

Bachmann, S. and Eichler-Lobermann, B. (2010). Soil phosphorus pools as affected by application of poultry litter ash in combination with catch crop cultivation. Commun. Soil. Sci. Pl. Anal., 41: 1098-1111

Beri, V. and Gupta, A. P. (2003). Recycling of rural and urban organic wastes: a review. Department of Soil Science, Punjab Agricultural University, Ludhiana, India.

Bohn, L., Meyer, A. and Rasmussen, S. (2008). Phytate: 
impact on environment and human nutrition. A challenge for molecular breeding. J. Zhejiang. Univ. Sci., 9: 165-191

Bolan, N. S., Adriano, D. C. and Mahimairaja, S. (2004). Distribution and bioavailability of trace elements in livestock and poultry manure byproducts. Crit. Rev. Environ. Sci. Technol., 34: 291-338

Cakmak, I. (2008). Enrichment of cereal grains with zinc: agronomic or genetic biofortification. Pl. Soil, 302: 1-17

Demeyer, A., Nkana, J. C. V. and Verloo, M. G. (2001). Characteristics of wood ash and influence on soil properties and nutrient uptake: an overview. Bioresour. Tech., 77: 287-295

Fageria, N. K. (2014). Yield and yield components and phosphorus use efficiency of lowland rice genotypes. $J$. Pl. Nutr., 37: 979-989

Fan, M. S., Zhao, F. J., Fairweathertait, S., Poulton, P., Dunham, S. and McGrath, S. (2008). Evidence of decreasing mineral density in wheat grain over the last 160 years. J. Trace. Elem. Med. Biol., 22: 315-324

Giovannini, G. S., Benvenuti, S., Lucchesi and Giachetti, M. (1993). Soil Biota, Nutrient Cycling and Farming Systems. Lewis Publ. Boca Raton, FL.

Gupta, R. K., Amandeep-Singh, Yadvinder-Singh, Thind, H. S., Bijay-Singh and Varinderpal-Singh. (2013). Effect of rice husk ash and bagasse ash on inorganic phosphorus fractions and available phosphorus in an alkaline soil under rice (Oryza sativa L.) wheat (Triticum aestivum L.) cropping system. J. Indian. Soc. Soil. Sci., 61: 258260

Imtiaz, M., Alloway, B. J., Memon, M. Y., Khan, P., Siddiqui, S., Aslam, M. and Shah, S. K. H. (2006). Zinc tolerance in wheat cultivars as affected by varying levels of phosphorus. Commun. Soil. Sci. Pl. Anal., 37: 16891702

Izsaki, Z. (2014). Effects of Phosphorus supplies on the nutritional status of maize (Zea mays L.). Commun. Soil. Sci. Pl. Anal., 45: 516-529

Jackson, M. L. (1973). Soil Chemical Analysis. Prentice Hall of India, Private Limited, New Delhi Pp. 38-56

Jamil, M., Qasim, M., Umar, M. and Abdus-Subhan. (2004). Impact of organic wastes (bagasse ash) on the yield of wheat in calcareous soil. Int. J. Agri. Biol., 6: 468-470

Kutman, U. B., Yildiz, B. and Cakmak, I. (2011). Improved nitrogen status enhances zinc and iron concentrations both in the whole grain and the endosperm fraction of wheat. J. Cereal. Sci.. 53: 118-125

Ladha, J. K., Dawe, D., Pathak, H., Padre, A. T., Yadav, R. L., Bijay-Singh, Yadwinder-Singh, Singh, P. and Kundu, A. L. (2003). How extensive are yield declines in long-term rice-wheat experiments in Asia. Field. Crops. Res., 81: 159-180.

Ladha, J. K., Pathak, H., Krupnik, T. J., Six, J. and Vankessel, C. (2005). Efficiency of fertilizer nitrogen in cereal production: retrospect and prospects. Adv. Agron. 87: 85 $-156$.

Lopez, R., Padilla, E., Bachmann, S. and Eichler-Loebermann, B. (2009). Effects of biomass ashes on plant nutrition in tropical and temperate regions. J. Agric. Rural. Develop. Tropic. Subtropic. 110: 51-60.

Majeed, M. A., Ahmad, R., Tahir, M., Tanveer, A. and Ahmad, M. (2014). Effect of phosphorus fertilizer sources and rates on growth and yield of wheat (Triticum aes- tivum L.). Asian. J. Agric. Biol. 2: 14-19.

Mehla, D. S., Singh, J. P., Sekhon, K. S., Sihag, D. and Bhardwaj, K. K. (2006). Long-term effects of inorganic and organic inputs on yield and soil fertility in ricewheat cropping system in India. In: Proc.18th World Congress of Soil Science. Philadelphia, Pennsylvania, USA.

Memon, K. S. and Puno, H. K. (2005). Effect of different nitrogen and phosphorus levels on the yield and yield components of wheat variety Pavan. Indus. J. Pl. Sci. 4: 273-277.

Mitchell, C. C. and Black, E. D. (1997). Land application of boiler wood ash in the southeastern United States., pp. 201-224.

Mozaffari, M., Russelle, M. P. and Rosen, C. J. (2002). Nutrient supply and neutralizing value of alfalfa stem gasification ash. Soil. Sci. Soc. Am. J. 66: 171-178.

Murphy, K. M., Reeves, P. G., Jones, S. S. (2008). Relationship between yield and mineral nutrient concentrations in historical and modern spring wheat cultivars. Euphytica. 163: $381-390$

Njoku, C. and Mbah, N. C. (2012). Effect of burnt and unburnt rice husk dust on maize yield and soil physico-chemical properties of an Ultisol in Nigeria. Biol. Agric. Hortic., 28: $49-60$

Nwite, J. C., Igwe, C. A. and Obalum, S. E. (2011). The contributions of different ash sources to the improvement in properties of a degraded ultisol and maize production in southeastern Nigeria. Am-Eu. J. Sustain. Agric., 5: 34 $-41$

Okon, P. B., Ogeh, J. S. and Amalu, U. C. (2005). Effect of rice husk ash and phosphorus on some properties of acid sands and yield of okra. Common. Soil. Sci. Pl. Anal., 36: 833-845

Olsen, S. R., Cole, C. V., Watanabe, F. S. and Dean, L. A. (1954). Estimation of available phosphorous in soils by extraction with sodium bicarbonate. USDA Cir 939, 19.

Onwuka, M. I., Osodeke, V. K. and Okola, N. A. (2007). Amelioration of soil acidity using cocoa husk ash for maize production in Umudike area of South East Nigeria. Trop. Subtrop. Agroecosyst., 7: 41-45

Pareek. (2004). Effect of phosphorus, sulphur and zinc on growth, yield and nutrient uptake of wheat (Triticum aestivum L.). Indian. J. Agron., 49: 160-162

Patterson, S. J., Acharya, S. N. and Thomas, J. E. (2004). Integrated soil and crop management: barley biomass and grain yield and canola seed yield response to land application of wood ash. Agron. J., 96: 971-977

Prakash, N. B., Nagaraj, H., Guruswamy, K. T., Vishwanatha, B. N., Narayanswamy, C., Gowda, N. A. J., Vasuki, N. and Siddaramappa, R. (2007). Rice hull ash as a source of silicon and phosphatic fertilizers: effect on growth and yield of rice in coastal Karnataka, India. Int. Rice. Res., 32: 34-36

Priyadharshini, J. and Seran, T. H. (2009). Paddy husk ash as a source of potassium for growth and yield of cowpea (Vigna unguiculata L.). J. Agric. Sci., 4: 67-76

Ryan, M. H., McInerney, J. K., Record, I. R. and Angus, J. F. (2008). Zinc bioavailability in wheat grain in relation to phosphorus fertilizer, crop sequence and mycorrhizal fungi. J. Sci. Food. Agr., 88: 1208-1216

Saarsalmi, A., Malkonen, E. and Piirainen, S. (2001). Effects of wood ash fertilization on forest soil chemical properties. 
Silva. Fennica., 35: 355-368

Sammauria, R. and Yadav, R. S. (2010). Performance of fenugreek-pearlmillet system as influenced by phosphorus and zinc application to fenugreek. Ind. J. Agron., 55: 197-202

Schiemenz, K. and Eichler-Loebermann, B. (2010). Biomass ashes and their phosphorus fertilizing effect on different crops. Nutr. Cycl. Agroecosyst., 87: 471-482

Sihag, D., Singh, J. P., Mehla, D. S. and Bhardwaj, K. K. (2005). Effect of integrated use of inorganic fertilizers and organic materials on the distribution of different forms of nitrogen and phosphorus in soil. J. Indian. Soc. Soil. Sci., 53: 80-84

Stukenholtz, D. D., Olsen, R. J., Gogan, G. and Olson, R. A. (1966). On the mechanism of phosphorus-zinc interaction in corn nutrition. Soil. Sci. Soc. Am. J., 30: 759-763

Talashilkar, S. C. and Chavan, A. S. (1996). Effect of rice hull ash on yield and uptake of silicon and phosphorus by rice cultivars at different growth stages. J. Indian. Soc. Soil. Sci., 44: 340-342

Thind, H. S., Yadvinder-Singh, Bijay-Singh, Varinderpal-
Singh, Sharma, S., Vashistha, M. and Singh, G. (2012). Land application of rice husk ash, bagasse ash and coal fly ash: effects on crop productivity and nutrient uptake in rice-wheat system on alkaline loamy sand. Field. Crops. Res., 135: 137-144

Vance, E. D. (1996). Land application of wood-fired and combustion boiler ashes: an overview. J. Environ. Qual., 25: 937-944

Yadvinder-Singh, Gupta, R. K., Thind, H. S., Bijay-Singh, Varinderpal-Singh, Gurpreet-Singh, Jagmohan-Singh and Ladha, J. K. (2009). Poultry litter as a nitrogen and phosphorus source for the rice-wheat cropping system. Biol. Fertic. Soils., 45: 701-710

Zhang, Y., Deng, Y., Chen, R., Cui, Z., Chen, X., Yost, R., Zhang, F. and Zou, C. (2012). The reduction in zinc concentration of wheat grain upon increased phosphorus -fertilization and its mitigation by foliar zinc application. Pl. Soil., 361: 143-152

Zhang, Y. Q., Shi, R. L., Karim, M. R., Zhang, F. S. and Zou, C. Q. (2010). Iron and zinc concentrations in grain and flour of winter wheat as affected by foliar 